\title{
Knowledge and utilisation of National Health Insurance Scheme among adult patients attending a tertiary health facility in Lagos State, South-Western Nigeria
}

\begin{tabular}{|c|c|}
\hline \multicolumn{2}{|c|}{$\begin{array}{l}\text { Authors: } \\
\text { Abdulhakeem O. Abiola }^{1} \text { (D) } \\
\text { Temitope W. Ladi-Akinyemi }^{1} \\
\text { Oluwagbemiga A. Oyeleye }^{1} \\
\text { Ganiyat K. Oyeleke } \\
\text { Olufunke I. Olowoselu } \\
\text { Aisha T. Abdulkareem }\end{array}$} \\
\hline $\begin{array}{l}\text { Affiliations: } \\
{ }^{1} \text { Department o } \\
\text { Health and Prir } \\
\text { College of Med } \\
\text { of Lagos, Lagos }\end{array}$ & $\begin{array}{l}\text { Community } \\
\text { nary Care, } \\
\text { icine, University } \\
\text { Nigeria }\end{array}$ \\
\hline $\begin{array}{l}{ }^{2} \text { Department } \\
\text { Lagos Universi } \\
\text { Hospital, Lago }\end{array}$ & $\begin{array}{l}\text { f Medicine, } \\
\text { ty Teaching } \\
\text {, Nigeria }\end{array}$ \\
\hline $\begin{array}{l}{ }^{3} \text { Department } \\
\text { Health, Lagos } \\
\text { Teaching Hosp } \\
\text { Nigeria }\end{array}$ & $\begin{array}{l}\text { f Community } \\
\text { University } \\
\text { ital, Lagos, }\end{array}$ \\
\hline $\begin{array}{l}\text { Correspondin } \\
\text { Oluwagbemiga } \\
\text { gbengaoyeleye }\end{array}$ & $\begin{array}{l}\text { author: } \\
\text { Oyeleye, } \\
\text { 95@gmail.com }\end{array}$ \\
\hline $\begin{array}{l}\text { Dates: } \\
\text { Received: } 25 \\
\text { Accepted: } 15 \\
\text { Published: } 04\end{array}$ & $\begin{array}{l}\text { ec. } 2018 \\
\text { May } 2019 \\
\text { Sept. } 2019\end{array}$ \\
\hline $\begin{array}{l}\text { How to cite th } \\
\text { Abiola AO, Lad } \\
\text { Oyeleye OA, O } \\
\text { OlowoseluOI, } \\
\text { AT. Knowledge } \\
\text { of National He } \\
\text { Scheme amon } \\
\text { attending a te } \\
\text { facility in Lago } \\
\text { South-Wester } \\
\text { Prm Health Ca } \\
\text { 2019;11(1), a2 } \\
\text { doi.org/10.41 } \\
\text { v11i1.2018 }\end{array}$ & $\begin{array}{l}\text { is article: } \\
\text { i-Akinyemi TW, } \\
\text { yeleke GK, } \\
\text { Abdulkareem } \\
\text { and utilisation } \\
\text { alth Insurance } \\
\text { g adult patients } \\
\text { tiary health } \\
\text { State, } \\
\text { Nigeria. Afr J } \\
\text { re Fam Med. } \\
\text { 018. https:// } \\
2 / \text { phcfm. }\end{array}$ \\
\hline $\begin{array}{l}\text { Copyright: } \\
\text { C 2019. The A } \\
\text { Licensee: AOS } \\
\text { is licensed unc } \\
\text { Creative Comn } \\
\text { Attribution Lic }\end{array}$ & $\begin{array}{l}\text { uthors. } \\
\text { S. This work } \\
\text { er the } \\
\text { nons } \\
\text { ense. }\end{array}$ \\
\hline Read online: & \\
\hline 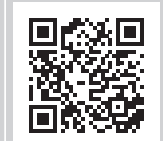 & $\begin{array}{l}\text { Scan this QR } \\
\text { code with your } \\
\text { smart phone or } \\
\text { mobile device } \\
\text { to read online. }\end{array}$ \\
\hline
\end{tabular}

Background: Despite the creation of the National Health Insurance Scheme (NHIS) by the Nigerian government, most Nigerians are not covered by the scheme.

Aim: The aim of this study was to assess the knowledge and utilisation of NHIS among adult patients who attended a tertiary health facility in Lagos state, South-Western Nigeria.

Setting: Outpatient clinic, Lagos State University Teaching Hospital, Ikeja, Lagos.

Methods: A descriptive cross-sectional study of 487 respondents recruited using a multi- stage sampling method. Data were collected using pretested semi-structured self-administered questionnaires, and analysis was done using Microsoft Excel 2007 and EPI Info 7 statistical software. Level of significance was set at $p<0.05$. Ethical approval was obtained from the Health Research Ethics Committee Lagos State university teaching Hospital.

Results: A total of 487 of the 500 self-administered questionnaires were retrieved and analysed, giving a response rate of $97.4 \%$. The study showed that $80.7 \%$ of the respondents had poor knowledge of NHIS, only $12.3 \%$ of the respondents had registered with the NHIS, and $43.8 \%$ of respondents who had not registered with NHIS claimed they do not know where to register. There was a statistically significant association between age and utilisation $(p=0.0007)$, marital status and utilisation of NHIS ( $p=0.016)$, employment status and utilisation of NHIS $(p=0.001)$. Most (96\%) of those who have utilised NHIS were satisfied with NHIS services.

Conclusion: Majority of the respondents had poor knowledge of NHIS and also majority of those who had registered were satisfied with the scheme. There should be increased awareness campaigns so that all Nigerians can benefit from the scheme.

Keywords: National Health Insurance Scheme; Lagos State University Teaching Hospital; LASUTH; patients; adults; knowledge of NHIS; utilisation of NHIS.

\section{Introduction}

The National Health Insurance Scheme (NHIS) is a type of formal sector social health insurance programme. ${ }^{1}$ In this programme, the cost of health care for an employee is paid for by the contributions of both the employee and the employer, which makes it a social health security system. ${ }^{1}$ This is made possible by deductions of $5 \%$ of the employee's salary and $10 \%$ of the employer's salary paid out to the employee on a monthly basis, the whole resources are then used to cover the health expenditures of all those enrolled under the scheme. ${ }^{2}$ The concept also involves that of subsidisation in which the young subsidise for the old, the rich subsidise for the poor and the healthy subsidises for the ill. ${ }^{2}$

The National Health Insurance Scheme aims at ensuring that every Nigerian has access to good healthcare services, protecting families from the financial hardship of huge medical bills. ${ }^{1}$ It also limits the rise in the cost of healthcare services, thereby maintaining high standard of healthcare delivery services within the system. ${ }^{1}$ It ensures both the efficiency in healthcare services and the availability of funds to the health sector for improved services, which guarantees equitable patronage of all of health care. ${ }^{1}$ The NHIS is seen as a complementary means of financing health care that is, to the government, international organisation and the whole community, a major factor necessary for the aim of achieving a worldwide level of good health that will lead to a productive and socially stable economy. ${ }^{3}$

The benefits of implementing the Compulsory Health Insurance Scheme includes three aspects: the scheme provides for the pooling of resources for cross subsidisation of health costs where 
those in high-income bracket subsidises those in low income bracket $^{1}$; the healthy subsidise the sick and the young subsidise the old ${ }^{1}$; the burden of funding healthcare services is shared between government and private employers and enrollees. ${ }^{1}$ Quackery is also minimised owing to standards for personnel and equipment set for providers by the scheme. ${ }^{1}$ Competition among healthcare providers to attract and retain clients leads to improvement in the quality of services. ${ }^{1}$ The scheme provides employment opportunities for health professionals in the healthcare delivery system and thereby reduces brain drain. ${ }^{3}$ Donor Agencies and/or government will have the confidence to donate to rural communities or less privileged through the proposed vulnerable group fund. ${ }^{3}$ Improved services resulting from improved income reduces the need for overseas treatment, thereby conserving the country's foreign reserve. ${ }^{3}$ Improved access to health care services create a healthier work force for increased economic activities and national prosperity. ${ }^{3}$ Communities and associations contribute for their health care services without viewing it as tax or levy, as they are the financial managers and administrators of their programme and reap the benefits from there. ${ }^{3}$

Members who are enrolled in this scheme get to enjoy several benefits and services such as hospital care (limited to only 15 days in a year and admission in the general ward), outpatient care, pharmaceutical care as in NHIS essential drug list, diagnostic tests as in NHIS diagnostic test list, maternal care for up to four (4) life births; preventive care (immunisation, health education, antenatal and postnatal care), eye care and preventive dental care. ${ }^{2}$ Beneficiaries no longer need to pay for treatment with cash in health centres when required except for the $10 \%$ co-payment for the price of drugs. ${ }^{2}$ This will reduce or even totally eliminate the usual habit of family members selling off their assets in order to generate money for treatment in emergency cases of life threatening conditions and illnesses. According to the ministry of health, it claims that the National Health Insurance Scheme is in fact the most comprehensive in the world owing to its benefit package. ${ }^{2}$

However, Nigeria remains the country with the highest number of out-of-pocket payments for healthcare, yet the health system is still very poor. ${ }^{4}$ The poor state of the health system was what led to the initiation and establishment of the National Health Insurance Scheme by the Nigerian Federal State. ${ }^{4}$ In 1997, its policy was drafted by the Nigerian government, which was then signed into law in 1999 and was launched for implementation on 16th June 2005. ${ }^{4}$ People die daily from common illnesses, which can be easily treated owing to financial incapacity. ${ }^{5}$ Many individuals borrow or loan money, sell their properties, use up all of their personal savings just to ensure they can pay for their health care. ${ }^{6,7}$

The major objective of the NHIS was to ensure that it covers all indigent Nigerians across the country with the purpose of delivering a comprehensive and affordable healthcare nationally. It comprises employers, employees, self-employed, unemployed and rural communities. ${ }^{2}$ The Nigerian health insurance scheme only covers $4 \%$ of the population, which is significantly low. ${ }^{8}$ Nine states have indicated interest in the scheme (Abia, Enugu, Gombe, Imo, Jigawa, Kaduna, Lagos, Ondo and Oyo) but only two states (Bauchi and Cross-river) attempted to enrol their employees in the scheme. ${ }^{9}$ The aim of this study was to identify the problems associated with the utilisation of the health insurance scheme.

The specific objectives of this study were to assess the knowledge of health insurance among adult patients to find out the degree of utilisation of health insurance among these patients and to determine some of the factors that affect the utilisation of health insurance among these patients in the Lagos State University Teaching Hospital, Ikeja.

\section{Methodology Description of study area}

The study was conducted in the adult outpatient department of the Lagos State University Teaching Hospital (LASUTH), formerly known as Ikeja General Hospital. The Lagos State University Teaching Hospital is a tertiary health institution situated in Ikeja, Local Government Area of Lagos State in South-western Nigeria. It is a multi-disciplinary tertiary hospital and it has a total bed space of 520. It is a major referral centre serving the whole of Lagos State, which is the economic nerve centre of Nigeria. It has many specialists' clinics and runs 24 hours-accident and emergency services and inpatient care services. ${ }^{10}$ Although the hospital is a tertiary healthcare facility, it also serves as a primary and secondary healthcare facility; hence, its services are affordable. Consultation and other services are rendered free of charge and only prescribed medicine and laboratory investigations are paid for by the patients.

\section{Methods}

The study was a descriptive cross-sectional study assessing the knowledge, attitude and the utilisation of NHIS among adult patients who were 18 years and above, attending the outpatient clinics of Lagos State University Teaching Hospital (LASUTH). The minimum sample size required for the study was approximately 465 using the Cochrane formula for crosssectional study:

$n=\mathrm{Z}^{2} \mathrm{p} \mathrm{q} / \mathrm{d}^{2}$

where $n=$ minimum sample size for a target population $\geq 10000$, $\mathrm{Z}=$ standard normal deviate corresponding to $95 \%$ confidence interval, $p=$ prevalence of attitude towards health insurance from a previous study, $q=1$-p and $d=$ degree of accuracy desired. The respondents were recruited using a multi-stage sampling method. In stage one: 10 of the 16 outpatient clinics present in LASUTH were selected by simple random sampling method using balloting procedure. In stage two, systematic sampling method was used to select respondents in the selected clinics.

The number of clients selected in each clinic was determined by proportionate allocation based on the statistics obtained from the administrative department. 


\section{Inclusion criteria}

Patients aged 18 years and above and also attending any of the outpatient clinics in LASUTH.

\section{Exclusion criteria}

Patients who were unconscious or had mental illness

\section{Data collection method}

Data were collected from the respondents in the clinics using a pretested, semi-structured self-administered questionnaire. The questionnaire was divided into three sections: (1) Section A: Socio-demographic characteristics of the respondents such as age, sex, tribe, level of education, employment status, (2) Section B: Knowledge about National Health Insurance Scheme and (3) Section C: Utilisation of National Health Insurance Scheme.

\section{Data analysis}

Data were analysed using Microsoft Excel 2010 and EPI info software version 7 , a public domain software developed by Centre for Disease Control and prevention (CDC). Data were summarised using means, standard deviation and proportions. The data were presented using tables. Relationships between categorical variables were tested using the Chi-square test and Fisher's exact test. Relationships between continuous variable were tested using the student $t$-test $p$-value $\leq 0.05$ was considered statistically significant.

\section{Scoring system}

The knowledge questions were scored and the overall grade was ascertained. One point was awarded for each correct answer given to the questions and no point was awarded for incorrect or 'I don't know' responses.

Knowledge had a total score of 11 and knowledge was graded as either poor (score of 0-6) or good (score of 7-11).

\section{Ethical considerations}

Ethical approval was obtained from the Health Research Ethics Committee of LASUTH (LREC. 06/10/912). Verbal permission for the study was obtained from the Doctors and Matrons on duty in the outpatient clinics. Informed consent was also obtained from each respondent. The confidentiality of information collected was secured by restricting access to the data collected to investigator and research assistants. Anonymity of the respondents was ensured by not including the personal details of the respondents in the instrument. Respondents were assured that their responses will not be used against them and it will not influence the care they will receive in the facility.

\section{Results}

A total of 487 of the 500 administered questionnaires were retrieved and analysed giving a response rate of $97.4 \%$.
The mean age of the respondents was $34.1 \pm 12.1$ years. Among the respondents, $35.3 \%$ were in the age range of 21-30 years, $56.7 \%$ were married, $54.0 \%$ were females, $65.5 \%$ were Christians, $58.7 \%$ had tertiary education, and $32.7 \%$ were civil servants (Table 1 ).

\section{Knowledge}

Only $7.2 \%$ of the respondents knew that NHIS does not provide maternity care for more than four live births for every insured person. Eleven point one percent (11.1\%) of the respondents knew the total monthly contribution by both the formal sector employee and employer, and $13.6 \%$ of the respondents knew the percentage of the employee's wages to be contributed by the employee (Table 2).

\section{Utilisation}

Most (87.7\%) of the respondents have not registered with the NHIS and $43.8 \%$ of those who have not registered did not know where to register. Most (83.3\%) of the respondents who had registered with NHIS had utilised the scheme for treatment in the last 6 months. Only $10 \%$ of those who have registered with NHIS have utilised it for surgical treatment. Majority (96.0\%) of those who had utilised the NHIS claimed that they are satisfied with the healthcare services provided by the scheme (Table 3 ).

TABLE 1: Socio-demographic characteristics of the respondents $(n=487)$.

\begin{tabular}{|c|c|c|}
\hline Variables & Frequency & Percentage \\
\hline \multicolumn{3}{|l|}{ Age (years) } \\
\hline$>18$ & 57 & 11.7 \\
\hline $21-30$ & 172 & 35.3 \\
\hline $31-40$ & 140 & 28.8 \\
\hline $41-50$ & 72 & 14.8 \\
\hline 51 and above & 46 & 9.4 \\
\hline Mean \pm s.d. & $34.1 \pm 12.1$ & - \\
\hline \multicolumn{3}{|l|}{ Sex } \\
\hline Male & 224 & 46.0 \\
\hline Female & 263 & 54.0 \\
\hline \multicolumn{3}{|l|}{ Religion } \\
\hline Christian & 319 & 65.5 \\
\hline Muslim & 157 & 32.2 \\
\hline Others & 11 & 2.3 \\
\hline \multicolumn{3}{|l|}{ Marital status } \\
\hline Single & 184 & 37.8 \\
\hline Married & 276 & 56.7 \\
\hline Divorced/Separated/widow & 27 & 5.5 \\
\hline \multicolumn{3}{|l|}{ Highest level of education } \\
\hline No formal education & 15 & 3.1 \\
\hline Primary education & 20 & 4.1 \\
\hline Secondary education & 166 & 34.1 \\
\hline Tertiary education & 286 & 58.7 \\
\hline \multicolumn{3}{|l|}{ Employment status } \\
\hline Civil servant & 159 & 32.7 \\
\hline Private sector & 104 & 21.4 \\
\hline Self-employed & 134 & 27.5 \\
\hline Student & 54 & 11.1 \\
\hline Unemployed & 36 & 7.3 \\
\hline
\end{tabular}

s.d., standard deviation. 


\begin{tabular}{|c|c|c|}
\hline & Frequency & Percentage \\
\hline The NHIS is based on the concept of social health insurance & 252 & 51.8 \\
\hline The NHIS aims to ensure that every Nigerian has access to good health care services & 348 & 71.7 \\
\hline The NHIS does not provide maternity care for up to five (5) live births for every insured person & 35 & 7.2 \\
\hline The NHIS implementation is in phases, starting with employees in the formal sector (public and private) & 250 & 51.3 \\
\hline The NHIS makes provision for vulnerable groups & 73 & 15.0 \\
\hline A contribution made by the insured person entitles him or herself, spouse and four (4) children under the age 18 years & 241 & 49.5 \\
\hline The total monthly contribution by both the formal sector employee and employer is not $20 \%$ of his or her wages & 54 & 11.1 \\
\hline The employee is to pay $5 \%$ of his or her wages & 66 & 13.6 \\
\hline Health Maintenance Organisations are the financial managers of NHIS & 124 & 25.5 \\
\hline $\begin{array}{l}\text { Capitation is the sum of money paid monthly by the HMOs to healthcare providers on behalf of a contributor whether or not services are } \\
\text { rendered by the healthcare provider }\end{array}$ & 111 & 22.8 \\
\hline An insured person pays $10 \%$ of the actual cost of drugs & 72 & 14.9 \\
\hline
\end{tabular}

NHIS, National Health Insurance Scheme, HMOs, health maintenance organisations.

TABLE 3: Respondents' utilisation of National Health Insurance Scheme.

\begin{tabular}{lcc}
\hline Variables & Frequency & Percentage \\
\hline Have you registered with NHIS $(\boldsymbol{n}=\mathbf{4 8 7})$ & 60 & 12.3 \\
Yes & 427 & 87.7 \\
No & & \\
If you have not registered with NHIS, state the & & \\
reasons why you have not registered $(\boldsymbol{n}=\mathbf{4 2 7})$ & 187 & 43.8 \\
I don't know where to register & 71 & 16.6 \\
I am not interested in NHIS & 66 & 15.5 \\
I do not have time to register & 103 & 24.1 \\
Others & & \\
Have you obtained your NHIS card $(\boldsymbol{n}=\mathbf{6 0})$ & 47 & 78.3 \\
Yes & 13 & 21.7 \\
No & & \\
Have you utilised NHIS for treatment in the last & & \\
$\mathbf{6}$ months $(\boldsymbol{n}=\mathbf{6 0})$ & 50 & 83.3 \\
Yes & 10 & 16.7 \\
No & & \\
Have you utilised the NHIS for Surgery $(\boldsymbol{n}=\mathbf{6 0})$ & 6 & 10.0 \\
Yes & 54 & 90.0 \\
No & & \\
Are you satisfied with NHIS services $(\boldsymbol{n}=\mathbf{5 0})$ & 48 & 96.0 \\
Yes & 1 & 2.0 \\
No & & \\
I don't know & & \\
\hline
\end{tabular}

NHIS, National Health Insurance Scheme.

\section{Factors affecting utilisation of health insurance}

Table 4 looks at variables associated with knowledge of NHIS and shows that those with education were more likely to have better knowledge of NHIS and to register with the scheme. Table 5 looks at variables associated with registration with NHIS and shows that those who were older registered more because they were at risk of more diseases. Table 6 also looks at variables associated with utilisation of NHIS and shows that those who were married utilised the services of NHIS more because it covers an individual, a spouse and four family members.

\section{Discussion}

More than one-third of the respondents were between 21 and 30 years' age range with a mean age of 34.1 (12.1 standard deviation [s.d.]). This is in contrast to a similar study conducted in rural southwest of Nigeria where about $69 \%$ of the respondents belong to the age range of 24-45 with the mean age of 39 (7.12 s.d.). ${ }^{4}$ The study also revealed that more than half of the respondents were married, which means that the NHIS scheme is expected to get more populated because a married individual can also register other members of the family into the scheme. More than half of the respondents had tertiary education, which was in contrast with the findings from the study in the rural southwest of Nigeria, where most of the respondents (63.2\%) were Primary/ secondary school leavers. This may be because this study was conducted in a tertiary health facility in Lagos state.

Furthermore, the results of this study revealed that less than one-third of the respondents have good knowledge of NHIS, which is consistent with findings from a similar study carried out in Lagos state among primary healthcare managers in which $17.9 \%$ had good knowledge $\mathrm{e}^{11}$ and another study among dentists which showed that only $28.7 \%$ had good knowledge. ${ }^{12}$ This is strange because it is expected that medical and dental practitioners should have good knowledge of NHIS. The study also revealed that over two-thirds of the respondents knew the objectives of NHIS; this is in contrast to a similar study where only $38.8 \%$ knew the objectives, ${ }^{13}$ and also another study where only $26.7 \%$ knew the objectives. ${ }^{14}$

According to this study, less than one-fifth of the respondents have registered with the NHIS, which is similar to the study carried out in secondary health facilities in Lagos state, where only $10.1 \%$ of the respondents registered with NHIS. ${ }^{15}$ However, the findings of this study is higher than that of a similar study in Osun state, where only $0.3 \%$ of respondents had registered with the scheme and another where just one respondent out of 4873 respondents was registered. ${ }^{13}$ Although a similar study in Oyo state showed that $83.2 \%$ of the respondents who were majorly civil servants had registered with the NHIS because it was made compulsory among government workers in the formal sector, but only $58.9 \%$ had started utilising the services. ${ }^{16}$ In another study among University workers, only $49.8 \%$ claimed they had registered with the scheme. ${ }^{17}$

In this study, over three-quarters of those who registered have obtained their NHIS cards. It was found out that most 
TABLE 4: Factors affecting knowledge of National Health Insurance Scheme among respondents $(n=487)$.

\begin{tabular}{|c|c|c|c|}
\hline \multirow[t]{2}{*}{ Variables } & \multicolumn{2}{|c|}{ Knowledge of NHIS } & \multirow[t]{2}{*}{$p$} \\
\hline & Poor, $n=393$ & Good, $n=94$ & \\
\hline Age (years) & & & 0.160 \\
\hline Mean \pm s.d. & $2.5 \pm 1.9$ & $6.7 \pm 1.0$ & \\
\hline Sex & & & 0.166 \\
\hline \multicolumn{4}{|l|}{ Male } \\
\hline Frequency (n) & 185 & 39 & \\
\hline Frequency $(\%)$ & 47.1 & 41.5 & \\
\hline \multicolumn{4}{|l|}{ Female } \\
\hline Frequency (n) & 208 & 55 & \\
\hline Frequency $(\%)$ & 52.9 & 58.5 & \\
\hline Religion & & & $0.112 *$ \\
\hline \multicolumn{4}{|l|}{ Christian } \\
\hline Frequency (n) & 249 & 70 & \\
\hline Frequency $(\%)$ & 63.4 & 74.5 & \\
\hline \multicolumn{4}{|l|}{ Muslim } \\
\hline Frequency (n) & 135 & 22 & \\
\hline Frequency $(\%)$ & 34.4 & 23.4 & \\
\hline \multicolumn{4}{|l|}{ Others } \\
\hline Frequency (n) & 9 & 2 & \\
\hline Frequency $(\%)$ & 2.2 & 2.1 & \\
\hline Marital status & & & $0.321 *$ \\
\hline \multicolumn{4}{|l|}{ Single } \\
\hline Frequency (n) & 152 & 32 & \\
\hline Frequency $(\%)$ & 38.7 & 34.0 & \\
\hline \multicolumn{4}{|l|}{ Married } \\
\hline Frequency (n) & 216 & 59 & \\
\hline Frequency $(\%)$ & 55.0 & 62.8 & \\
\hline \multicolumn{4}{|l|}{ Divorced/separated/widow } \\
\hline Frequency (n) & 25 & 3 & \\
\hline Frequency $(\%)$ & 6.3 & 3.2 & \\
\hline Highest level of education & & & $0.050 *$ \\
\hline \multicolumn{4}{|l|}{ No formal education } \\
\hline Frequency (n) & 13 & 2 & \\
\hline Frequency $(\%)$ & 3.3 & 2.1 & \\
\hline \multicolumn{4}{|l|}{ Primary } \\
\hline Frequency (n) & 20 & 0 & \\
\hline Frequency $(\%)$ & 5.1 & 0.0 & \\
\hline \multicolumn{4}{|l|}{ Secondary } \\
\hline Frequency (n) & 137 & 29 & \\
\hline Frequency $(\%)$ & 34.9 & 30.9 & \\
\hline \multicolumn{4}{|l|}{ Tertiary } \\
\hline Frequency (n) & 223 & 63 & \\
\hline Frequency (\%) & 56.7 & 67.0 & \\
\hline Employment status & & & 0.208 \\
\hline \multicolumn{4}{|l|}{ Civil servant } \\
\hline Frequency (n) & 121 & 38 & \\
\hline Frequency $(\%)$ & 30.8 & 40.4) & \\
\hline \multicolumn{4}{|l|}{ Private sector } \\
\hline Frequency (n) & 88 & 16 & \\
\hline Frequency (\%) & 22.4 & 17.0 & \\
\hline Self-employed & & & \\
\hline Frequency (n) & 106 & 28 & \\
\hline Frequency $(\%)$ & 27.0 & 29.8 & \\
\hline Student & & & \\
\hline Frequency (n) & 48 & 6 & \\
\hline Frequency $(\%)$ & 12.2 & 6.4 & \\
\hline Unemployed & & & \\
\hline Frequency (n) & 30 & 6 & \\
\hline Frequency $(\%)$ & 7.6 & 6.4 & \\
\hline
\end{tabular}

TABLE 4 (Continues...): Factors affecting knowledge of National Health Insurance Scheme among respondents ( $n=487$ ).

\begin{tabular}{lccc}
\hline Variables & \multicolumn{2}{c}{ Knowledge of NHIS } & $p$ \\
\cline { 2 - 3 } & Poor, $\boldsymbol{n = 3 9 3}$ & Good, $\boldsymbol{n = 9 4}$ & \\
\hline NHIS registration & & & $0.023^{*}$ \\
Yes & & & \\
$\quad$ Frequency (n) & 42 & 18 & \\
$\quad$ Frequency (\%) & 10.7 & 19.1 & \\
No & & & \\
$\quad$ Frequency (n) & 351 & 76 & \\
Frequency (\%) & 89.3 & 80.9 & \\
\hline
\end{tabular}

NHIS, National Health Insurance Scheme; s.d., standard deviation.

*, Fisher's exact.

TABLE 5: Factors affecting registration with National Health Insurance Scheme $(n=487)$.

\begin{tabular}{|c|c|c|c|}
\hline \multirow[t]{2}{*}{ Variables } & \multicolumn{2}{|c|}{ Registration with NHIS } & \multirow[t]{2}{*}{$p$} \\
\hline & Yes, $n=60$ & No, $n=427$ & \\
\hline Age (years) & & & 0.001 \\
\hline Mean \pm s.d. & $38.9 \pm 14.5$ & $33.5 \pm 11.6$ & \\
\hline Sex & & & 0.239 \\
\hline Male & 25 & 199 & \\
\hline Frequency (\%) & 41.7 & 46.6 & \\
\hline Female & 35 & 228 & \\
\hline Frequency $(\%)$ & 58.3 & 53.4 & \\
\hline Religion & & & $0.711^{*}$ \\
\hline Christian & 40 & 279 & \\
\hline Frequency $(\%)$ & 66.7 & 65.3 & \\
\hline Muslim & 18 & 139 & \\
\hline Frequency $(\%)$ & 30.0 & 32.6 & \\
\hline Others & 2 & 9 & \\
\hline Frequency $(\%)$ & 3.3 & 2.1 & \\
\hline Marital status & & & $0.169 *$ \\
\hline Single & 19 & 165 & \\
\hline Frequency $(\%)$ & 31.7 & 38.6 & \\
\hline Married & 40 & 236 & \\
\hline Frequency $(\%)$ & 66.7 & 55.3 & \\
\hline Divorced/separated/widow & 1 & 26 & \\
\hline Frequency $(\%)$ & 1.6 & 6.1 & \\
\hline Highest level of education & & & $0.273^{*}$ \\
\hline No formal education & 0 & 15 & \\
\hline Frequency (\%) & 0.0 & 3.5 & \\
\hline Primary & 1 & 19 & \\
\hline Frequency $(\%)$ & 1.7 & 4.4 & \\
\hline Secondary & 18 & 148 & \\
\hline Frequency (\%) & 30.0 & 34.7 & \\
\hline Tertiary & 41 & 245 & \\
\hline Frequency (\%) & 68.3 & 57.4 & \\
\hline Employment status & & & $0.001 *$ \\
\hline Civil servant & 24 & 135 & \\
\hline Frequency $(\%)$ & 40.0 & 31.6 & \\
\hline Private sector & 20 & 84 & \\
\hline Frequency (\%) & 33.3 & 19.7 & \\
\hline Self-employed & 1 & 133 & \\
\hline Frequency (\%) & 1.7 & 31.1 & \\
\hline Student & 13 & 41 & \\
\hline Frequency $(\%)$ & 21.7 & 9.6 & \\
\hline Unemployed & 2 & 34 & \\
\hline Frequency $(\%)$ & 3.3 & 8.0 & \\
\hline
\end{tabular}

of those registered rarely used the NHIS for surgical services. This may be because most of the surgical procedures are not covered by the NHIS and patient has to pay out-of-pocket for such procedures. Almost half of the respondents used NHIS 
TABLE 6: Factors affecting utilisation of National Health Insurance Scheme among respondents $(n=487)$.

\begin{tabular}{|c|c|c|c|}
\hline \multirow[t]{2}{*}{ Variables } & \multicolumn{2}{|c|}{ Registration with NHIS } & \multirow[t]{2}{*}{$p$} \\
\hline & Yes, $n=60$ & No, $n=427$ & \\
\hline Age (years) & & & 0.0007 \\
\hline Mean \pm s.d. & $39.6 \pm 12.3$ & $33.5 \pm 11.9$ & \\
\hline Sex & & & 0.369 \\
\hline Male & 20 & 204 & \\
\hline Frequency $(\%)$ & 40.0 & 46.7 & \\
\hline Female & 35 & 233 & \\
\hline Frequency $(\%)$ & 58.3 & 53.3 & \\
\hline Religion & & & $0.435 *$ \\
\hline Christian & 34 & 285 & \\
\hline Frequency $(\%)$ & 68.0 & 65.2 & \\
\hline Muslim & 14() & 143 & \\
\hline Frequency $(\%)$ & 28.0 & 32.7 & \\
\hline Others & 2 & 9 & \\
\hline Frequency $(\%)$ & 4.0 & 2.1 & \\
\hline Marital status & & & $0.016 *$ \\
\hline Single & 13 & 171 & \\
\hline Frequency $(\%)$ & 26.0 & 39.1 & \\
\hline Married & 37 & 239 & \\
\hline Frequency $(\%)$ & 74.0 & 54.7 & \\
\hline Divorced/separated/widow & 0 & 27 & \\
\hline Frequency $(\%)$ & 0.0 & 6.2 & \\
\hline Highest level of education & & & $0.483 *$ \\
\hline No formal education & 0 & 15 & \\
\hline Frequency $(\%)$ & 0.0 & 3.4 & \\
\hline Primary & 1 & 19 & \\
\hline Frequency $(\%)$ & 2.0 & 4.3 & \\
\hline Secondary & 15 & 151 & \\
\hline Frequency (\%) & 30.0 & 34.6 & \\
\hline Tertiary & 34 & 252 & \\
\hline Frequency $(\%)$ & 68.0 & 57.7 & \\
\hline Employment status & & & $0.001 *$ \\
\hline Civil servant & 20 & 139 & \\
\hline Frequency (\%) & 40.0 & 31.8 & \\
\hline Private sector & 16 & 88 & \\
\hline Frequency $(\%)$ & 32.0 & 20.1 & \\
\hline Self-employed & 1 & 133 & \\
\hline Frequency (\%) & 2.0 & 30.4 & \\
\hline Student & 11 & 43 & \\
\hline Frequency (\%) & 22.0 & 9.8 & \\
\hline Unemployed & 2 & 34 & \\
\hline Frequency $(\%)$ & 4.0 & 7.9 & \\
\hline
\end{tabular}

to treat medical ailment, which is similar to a study carried out in Ibadan where $52.9 \%$ of the respondents utilised the NHIS to also treat medical ailments such as Malaria. ${ }^{18}$ It was also found out that a very high percentage of the respondents were satisfied with the healthcare services provided by the NHIS. This finding was higher than that of a similar study in Oyo state where about $60 \%$ of the respondents were also satisfied with the scheme. ${ }^{16}$

Respondents who had attained tertiary level of education had more knowledge of NHIS and therefore registered with the scheme compared with respondents who had a lower level of education. In addition, it was also found out that age and employment status are determining factors for registration with the NHIS. Majority of the respondents who were civil servants registered with the NHIS as it is made mandatory by the government for this category of workers. Furthermore, respondents who were married utilised the NHIS services more because the scheme covers a registered member, a spouse and four children. Older respondents tend to have increased morbidity; hence they require the services of NHIS than respondents who are younger and healthy.

In summary, the study demonstrates that majority of the respondents have poor knowledge of NHIS. Majority of the respondents have not registered with the NHIS and their excuse was that they did not know where to register. A large percentage of the respondents who had registered claimed they are satisfied with the services provided by the scheme. There were significant association between age, and employment status of the respondents and their registration and utilisation of NHIS.

\section{Limitations}

A potential bias in this study was recall. However, recall bias was reduced by limiting enquiries on utilisation of NHIS to the last 6 months. This may tend to underestimate the level of utilisation. Another limitation was that the implementation of the NHIS outside of the original intentions and policy framework accounted for the poor utilisation measured. Also, this is a facility-based study and the results cannot be generalised to the general population.

\section{Conclusion}

Majority of the respondents involved in this study had poor knowledge of the NHIS, but majority of those who had registered were satisfied with the services of the NHIS. Those who had not registered with the NHIS claimed they do not know where to register. There should be increased awareness campaigns on all forms of media with emphasis on locations of registration centres and a step-by-step process of how to register with the scheme. The government should ensure that the NHIS is mandatory for both the formal and informal sector employee so that all Nigerians can benefit from the scheme.

\section{Acknowledgements}

The authors would like to acknowledge Adetunji Emmanuel Adekunle for his contribution towards the collection and analysis of data in this study, and also Onochie Martins for his intellectual contributions and review of this study.

\section{Competing interests}

The authors declare that they have no financial or personal relationships that may have inappropriately influenced them in writing this article.

\section{Authors' contributions}

A.O.A. was the project leader, reviewed the result of data analysis, reviewed the manuscript and was responsible for project design and data collection. O.A.O. was responsible for data collection, data entry, data analysis and co-wrote the 
manuscript. T.W.L-A., G.K.O., O.I.O. and A.T.A. were responsible for data collection, project design and review of the manuscript.

\section{Funding information}

This research received no specific grant from any funding agency in the public, commercial or not-for-profit sectors.

\section{Data availability statement}

Data will be made available on request.

\section{Disclaimer}

The views expressed in the submitted article are that of the authors and not an official position of the institution or funder.

\section{References}

1. Ministry of Health, Federal Republic of Nigeria. National Health Insurance Scheme Handbook. Operational Guidelines on National Health Insurance Scheme 2006. National Health Insurance Scheme. Niger Med Pract. 2003;43(2):2.

2. Onyedibe KI, Goyit MG, Nnadi NE. An evaluation of the National Health Insurance Scheme (NHIS) in Jos, a north-central Nigerian city. Glob Adv Res JMicrobiol. 2012;1(1):005-012.

3. Gov.ng. National Health Insurance Scheme Operational guidelines. Vol. 10. Garki, Abuja: NHIS, 2012; p. 5-12.

4. Eteng IE, Utibe EE. The National Health Insurance Scheme and its implication for elderly care in Nigeria. Int JSciRes. 2015;4(2):144-148.

5. Adewole DA, Adebayo AM, Udeh EI, Shaahu VN, Dairo MD. Payment for health care and perception of the Nigerian Health Insurance Scheme in a rural area in southwest Nigeria. AmJ Trop Med Hyg. 2015;93(3):648-654. https://doi. org/10.4269/ajtmh.14-0245
6. Carapinha JL, Ross Degnan D, Desta AT, Wagner AK. Health insurance systems in five sub-Saharan African countries: Medicine benefits and data for decision making. Health Policy. 2011;99:193-202. https://doi.org/10.1016/j.healthpol.2010.11.009

7. Mathauer I, Schmidt JO, Wenyaa M. Extending social health insurance to the informal sector in Kenya. An assessment of factors affecting demand. Int J Health Plann Manage. 2008;23:51-68. https://doi.org/10.1002/hpm.914

8. Onoka CA, Onwujekwe OE, Uzochukwu BS, Ezumah NN. Promoting universal financial protection: Constraints and enabling factors in scaling-up coverage with social health insurance in Nigeria. Health Res Policy Syst. 2013;11:20. https://doi. org/10.1186/1478-4505-11-20

9. Uzochukwu B, Ughasoro MD, Etiaba E, Okwuosa C, Enwulau E. Health care financing in Nigeria: Implications for achieving universal health coverage. Niger J ClinPract. 2015;18:437-444. https://doi.org/10.4103/1119-3077.154196

10. Akinlade AT, Ogbera AO, Fasanmade OA. Serum C-peptide assay of patients with hyperglycemic emergencies at the Lagos State University Teaching Hospital (LASUTH) Ikeja. Int Arch Med. 2014;7:50, 61-63. https://doi.org/10.1186/1755-7682-7-50

11. Karatu DL, Olufunlayo TF, Onigbogi OO. Knowledge of health insurance among primary health-care managers in Shongom LGA, Gombe State, Nigeria. NigQ Hosp Med. 2012;22(1):18-21.

12. Adeniyi AA, Onajole AT. The National Health Insurance Scheme (NHIS): A survey of knowledge and opinions of Nigerian dentists in Lagos. Afr J Med Sci. 2010;39(1):29-35.

13. Olugbenga-Bello Al, Adebimpe WO. Knowledge and attitude of civil servants in Osun state Southwestern Nigeria towards the national health insurance. Niger J Clin Pract. 2010;13(4):421-426.

14. Sabitu K, James E. Knowledge, attitudes and opinions of health care providers in Minna town towards the national health insurance scheme (NHIS). Ann Niger Med. 2005;1(2):9-13.

15. Okusanya BO, Roberts AA, Akinsola OJ, Oye-Adeniran BA. Birth plans and health insurance enrolment of pregnant women: $A$ cross-sectional survey at two secondary health facilities in Lagos, Nigeria. J Matern Fetal Neonatal Med. 2016;29(16):2602-2606.

16. Sanusi RA, Awe AT. An assessment of awareness of level of National Health Insurance Scheme (NHIS) among health care consumers in Oyo State, Nigeria. Medwell J. 2009;4(2):143-148.

17. Adibe MO, Udeogaranya PO, Ubaka CM. Awareness of National Health Insurance Scheme (NHIS) activities among employees of a Nigerian University. Int J Drug Dev Res. 2011;3(4):78-85.

18. Osungbade KO, Obembe TA, Oludoyi A. User's satisfaction with services provided under National Health Insurance Scheme in South Western Nigeria. Int J Trop Dis Health. 2014;4(5):595-607. https://doi.org/10.9734/IJTDH/2014/7280 